\title{
Hubungan Efikasi Diri dengan Kecemasan Menyusun Skripsi pada Mahasiswa Keperawatan
}

\author{
Niken Saraswati $^{1 *}$, Meidiana Dwidiyanti ${ }^{1}$, Agus Santoso ${ }^{1}$, Diyan Yuli Wijayanti ${ }^{1}$ \\ ${ }^{1}$ Departemen Ilmu Keperawatan Fakultas Kedokteran, \\ Universitas Diponegoro, Semarang, Indonesia \\ nikensaraswati27@gmail.com
}

\begin{abstract}
Introduction: Students who writing their thesis experience difficulties during the COVID-19 pandemic result in anxiety. The feeling can arise due to a low self-efficacy that view difficult experiences as threats and think about the possibility of failure. Previous studies show different relationship between selfefficacy and anxiety thus requires further research particularly in seeking the relationship of selfefficacy and anxiety on thesis's writing among undergraduate nursing students.

Methods: This study was a correlational study with all of undergraduate nursing students who is writing a thesis as the population. Subjects (112 students) were selected by a proportionate stratified random sampling method. Questionnaires used in this study were General Self-Efficacy Scale (GSES) and Zung Self Rating Anxiety Scale (ZSRAS). Data analysis was performed by Pearson Correlation tests.

Results: Main results distinguished that there is a negative relationship between self-efficacy and anxiety of undergraduate nursing students who is writing a thesis with $r=-0.445$ which is indicate that the relationship between two variable is strong enough.

Discussion: Students need to make a list of goals to be achieved, so they are encouraged to try to achieve these goals more. Moreover, students can conduct a variety of things to reduce their anxiety.
\end{abstract}

Keywords: COVID-19 Outbreak, Self-Efficacy, Thesis Writing Anxiety.

\begin{abstract}
Abstrak
Pendahuluan: Mahasiswa yang sedang menyusun skripsi menghadapi banyak tantangan selama pandemi COVID-19 sehingga cemas tentang skripsinya. Kecemasan tersebut timbul karena efikasi diri yang rendah dan memikirkan kemungkinan kegagalan. Beberapa penelitian sebelumnya menunjukkan perbedaan hubungan antara efikasi diri dan kecemasan sehingga membutuhkan penelitian lebih lanjut. Penelitian ini bertujuan untuk mengetahui adanya hubungan efikasi diri dan kecemasan menyusun skripsi pada mahasiswa keperawatan.

Metode: Penelitian ini merupakan studi korelasi dengan populasi mahasiswa keperawatan yang sedang menyusun skripsi. Subjek sebanyak 112 mahasiswa dipilih menggunakan teknik proportionate stratified random sampling. Kuesioner yang digunakan yaitu kuesioner General Self-Efficacy Scale (GSE) dan Zung Self Rating Anxiety Scale (ZSRAS). Analisis data dilakukan menggunakan uji korelasi Pearson.

Hasil: Hasil penelitian menunjukkan bahwa ada hubungan negatif antara efikasi diri dan kecemasan menyusun skripsi $(\mathrm{r}=-0,445)$ yang mengindikasikan bahwa hubungan antara dua variabel cukup kuat. Kesimpulan: Mahasiswa perlu membuat daftar tujuan yang ingin dicapai, sehingga terpacu untuk berusaha lebih mencapai tujuan tersebut. Mahasiswa juga dapat melakukan berbagai macam hal untuk mengurangi kecemasan yang terjadi.
\end{abstract}

Kata kunci: Pandemi COVID-19, Efikasi diri, Kecemasan Menyusun Skripsi. 


\section{PENDAHULUAN}

Mahasiswa menghadapi berbagai macam tantangan dalam pandemi COVID19. Perguruan tinggi memutuskan untuk mengubah metode pembelajaran secara daring yang berdampak negatif bagi psikologis mahasiswa. Mahasiswa mengalami stress disebabkan oleh ketidakpastian dan gangguan dalam proses belajarnya. Mahasiswa harus menghentikan atau menunda penelitian (Zhai \& Du, 2020). Mahasiswa tingkat akhir merupakan komponen yang juga terdampak COVID19. Mahasiswa harus menyelesaikan tugas akhir (skripsi) sebagai bagian dari persyaratan akhir pendidikan akademis. Penulisan skripsi menuntut mahasiswa untuk berpikir lebih keras dalam menentukan judul, mencari referensi, merancang penelitian dan dalam proses penelitian (Rismen, 2015). Pandemi COVID-19 menyebabkan mahasiswa menghadapi banyak kesulitan dalam pengerjaan skripsi, diantaranya adalah susahnya konsultasi, hambatan dalam penelitian, koneksi yang terkadang menghambat, dan perubahan dalam metode penelitian. Banyaknya tekanan yang dirasakan mahasiswa selama pengerjaan skripsi di tengah pandemi COVID-19 dapat menimbulkan kecemasan. Kecemasan adalah keadaan takut berlebihan sebagai akibat dari adanya konflik pada kehidupan seseorang atau biasanya muncul saat seseorang dituntut untuk beradaptasi dengan perubahan situasi yang terjadi dalam hidupnya (Rau, Rahman \& Randalembah, 2017).

Kecemasan adalah perasaan tidak berdaya dan tidak mampu saat seseorang dihadapkan pada kenyataan yang ada atau tuntutan hidup sehari-hari (Annisa \& Ifdil, 2016). Kecemasan tidak hanya bergantung pada faktor individu, tetapi juga dipengaruhi oleh sumber atau rangsangan yang membangkitkan kecemasan (Widodo et al., 2017).

Sebagian besar mahasiswa menghadapi kecemasan dalam menyusun proposal skripsi pada kategori sedang yaitu sebanyak 41,1\% (Kristianto et al., 2014). Sebanyak sembilan mahasiswa menyatakan cemas dalam menyusun skripsi. Penyebab cemas adalah terkait proses bimbingan, ketidakpercayaan diri, khawatir akan penelitian yang sulit, dan tuntutan dari orang tua. Gejala kecemasan yang dialami antara lain adalah sakit kepala, susah tidur, jantung berdebar-debar, mual, dan juga perubahan mood. Hal akan berakibat pada tertundanya bimbingan dan pengerjaan skripsi serta mundurnya target kelulusan (Listanto \& Demak, 2015). Hasil penelitian lain menunjukkan bahwa terdapat korelasi yang positif antara kecemasan dengan ekonomi, perubahan aktivitas harian dan juga penundaan dalam kegiatan belajar mengajar pada mahasiswa program sarjana kedokteran Universitas Changzhi China selama pandemi (Cao et al., 2020). Mahasiswa mengalami kecemasan, depresi dan stress dikarenakan sistem lockdown yang menyebabkan ketidakpastian sistem pembelajaran (Zhai \& Du, 2020). Hal tersebut menunjukkan bahwa mahasiswa yang mengerjakan skripsi selama masa pandemi rentan mengalami masalah kesehatan mental seperti kecemasan. Penting bagi mahasiswa untuk mengetahui penyebab kecemasan yang dialami, sehingga dapat belajar bagaimana cara mengatasi kecemasan dan meminimalisir terjadinya kecemasan di masa yang akan datang.

Salah satu cara untuk menyeimbangkan antara beban yang berat dan hasil yang maksimal adalah dengan memupuk rasa percaya pada kemampuan diri, sehingga akan muncul motivasi dan semangat untuk menyelesaikan tugas tepat waktu. Efikasi diri adalah keyakinan 
individu dalam memperkirakan kemampuannya dalam melaksanakan suatu tugas untuk mencapai hasil tertentu (Rustika, 2016). Efikasi diri dalam konteks ini adalah keyakinan mahasiswa tentang kemampuan dirinya untuk menyelesaikan suatu tugas. Efikasi diri menentukan bagaimana seseorang merasakan sesuatu, berpikir, memotivasi diri sendiri dan juga bertingkah laku (ALBaddareen et al., 2015).

Efikasi diri yang rendah menyebabkan tingkat kecemasan yang tinggi. Individu dengan efikasi diri yang rendah dan kecemasan yang tinggi cenderung memiliki perilaku menghindar. Tugas akademik merupakan hal yang tidak bisa dihindari oleh mahasiswa termasuk di dalamnya adalah tugas akhir atau skripsi. Efikasi diri yang rendah akan meningkatkan kecemasan dan perilaku menghindar. Perilaku menghindar dilakukan karena individu tidak mempunyai keyakinan bahwa dirinya dapat mengatasi masalahmasalah yang akan muncul (Rustika, 2016). Efikasi diri yang tinggi akan memberikan dampak yang positif bagi seseorang. Efikasi diri yang tinggi akan menuntun individu untuk menghadapi tuntutan tugas yang ada (Shofiah \& Raudatussalamah, 2014).

Kecemasan pada mahasiswa saat mengerjakan skripsi dapat timbul karena efikasi diri yang rendah. Mahasiswa dengan efikasi diri rendah mungkin melihat pengalaman sulit sebagai ancaman dan memikirkan kemungkinan kegagalan. Hal ini juga meningkatkan kecemasan (Shofiah \& Raudatussalamah, 2014).

Hasil penelitian pada siswa kelas IX MTS Al Hikmah Brebes yang akan melaksanakan ujian menunjukkan adanya hubungan antara efikasi diri dan kecemasan dengan nilai koefisien korelasi sebesar Niken Saraswati, dkk., Peningkatan Efikasi Diri Mahasiswa...
0,575. Hasil ini menunjukkan bahwa siswa dengan efikasi diri yang tinggi memiliki tingkat kecemasan yang rendah (Permana, Harahap, \& Astuti,, 2016). Hasil penelitian lain menunjukkan hasil berbeda dengan berbagai penelitian di atas yang menyatakan bahwa tidak ada korelasi antara gejala kecemasan dan efikasi diri mahasiswa (Faramarzi \& Khafri, 2017). Oleh karena itu perlu dilakukan penelitian lebih lanjut sehingga penelitian ini ingin mengetahui hubungan efikasi diri dan kecemasan pada mahasiswa keperawatan yang sedang menyusun skripsi.

\section{METODE}

Penelitian ini menggunakan pendekatan kuantitatif dengan metode korelasional. Populasi dalam penelitian ini adalah mahasiswa keperawatan yang sedang menyusun skripsi. Jumlah keseluruhan mahasiswa yang sedang menyusun skripsi adalah 156 mahasiswa yang terdiri dari 113 mahasiswa angkatan 2016, seorang mahasiswa angkatan 2013, seorang mahasiswa angkatan 2014, sebelas mahasiswa angkatan 2015 dan 30 mahasiswa lintas jalur. Jumlah sampel yang digunakan dalam penelitian ini adalah sebanyak 112 mahasiswa. Teknik pengambilan sampel yang digunakan adalah probability sampling dengan menggunakan proportionate stratified random sampling (Siyoto \& Sodik, 2015).

Sampel dalam penelitian ini adalah mahasiswa Keperawatan yang sedang menyusun skripsi dengan kriteria: 1). mahasiswa keperawatan yang sedang menyusun skripsi baik yang belum dan sudah melaksanakan seminar proposal; 2). mahasiswa yang mengalami kecemasan dari level ringan hingga panik; 3). mahasiswa yang memiliki dan dapat 
menggunakan smartphone; dan 4). bersedia menjadi responden. Kuesioner yang digunakan adalah Zung Self Rating Anxiety Scale (ZSRAS) untuk mengukur kecemasan dan kuesioner General Self-Efficacy Scale (GSES) untuk mengukur efikasi diri. Analisa data yang digunakan dalam penelitian ini adalah uji korelasi pearson. Penyebaran kuesioner dilakukan secara daring melalui aplikasi google form. Penelitian ini telah lolos kaji etik dari Komisi Etik Penelitian Kesehatan Departemen Ilmu Keperawatan Universitas Diponegoro dengan nomor 112/EC/KEPK/ D.Kep/VI/2020.

\section{HASIL}

Tabel 1. Efikasi Diri pada Mahasiswa Keperawatan yang sedang Menyusun Skripsi Mei $2020(n=112)$

\begin{tabular}{lllll}
\hline No. & $\begin{array}{c}\text { Efikasi } \\
\text { Diri }\end{array}$ & Skor & $\mathrm{f}$ & $\%$ \\
\hline 1. & Tinggi & $\geq 36,86$ & 104 & 92,9 \\
2. & Rendah & $<36,86$ & 8 & 7,1 \\
\hline & Total & & 112 & 100 \\
\hline
\end{tabular}

Tabel 2. Kecemasan pada Mahasiswa Keperawatan yang sedang Menyusun Skripsi Mei $2020(n=112)$

\begin{tabular}{clrrl}
\hline No. & Kecemasan & Skor & f & \multicolumn{1}{c}{$\%$} \\
\hline 1. & Rendah & $20-34$ & 34 & 30,4 \\
2. & Sedang & $35-49$ & 66 & 58,9 \\
3. & Berat & $50-64$ & 11 & 9,8 \\
4. & Panik & $65-80$ & 1 & 0,9 \\
\hline \multicolumn{2}{l}{ Total } & & 112 & 100 \\
\hline
\end{tabular}

Tabel 3. Hubungan Efikasi Diri dan Kecemasan Mahasiswa Keperawatan yang Menyusun Skripsi Bulan Mei $2020(\mathrm{n}=112)$

\begin{tabular}{|c|c|c|}
\hline Variabel & p-value & $r$ \\
\hline $\begin{array}{l}\text { Efikasi diri dan } \\
\text { Kecemasan }\end{array}$ & 0,00 & $-0,445$ \\
\hline
\end{tabular}

\section{PEMBAHASAN}

Penelitian menyimpulkan bahwa terdapat hubungan yang cukup kuat antara efikasi diri dan kecemasan. Hasil penelitian ini didukung oleh penelitian sebelumnya yang menunjukkan hasil adanya hubungan antara efikasi diri dan kecemasan dengan nilai koefisien korelasi sebesar -0,575 yang berarti bahwa siswa dengan efikasi diri yang tinggi memiliki tingkat kecemasan yang rendah ( Permana, Harahap, \& Astuti, 2016). Penelitian lain terkait efikasi diri dan kecemasan menghadapi kejuaraan nasional pada atlet menghasilkan nilai koefisien korelasi sebesar $-0,471$ dengan $p=0,000$. Hal tersebut berarti bahwa kedua variabel tersebut berhubungan dengan arah hubungan bersifat negatif sehingga apabila semakin tinggi efikasi diri atlet tenis, maka semakin rendah kecemasan atlet tenis lapangan Pelti Semarang dalam menghadapi kejuaraan nasional (Safitri \& Masykur, 2017). Peneliti menyimpulkan bahwa efikasi diri mempengaruhi kecemasan mahasiswa yang sedang mengerjakan skripsi.

Hasil penelitian ini berbeda dengan penelitian di Turkey yang menunjukkan bahwa tidak ada korelasi antara kecemasan dan efikasi diri. Mahasiswa jurusan bahasa asing mengalami kecemasan, namun tidak berkorelasi dengan efikasi diri. Kecemasan tetap tinggi baik pada mahasiswa dengan efikasi diri tinggi maupun rendah. Hal ini bisa terjadi karena sistem edukasi di Turki, pendidikan di sekolah dimana Sebagian besar mahasiswa berasal dari boarding school dan dari kota kecil. Pribadi yang pemalu, ketidakmampuan menyuarakan opini di depan publik dan jarangnya kesempatan untuk berbicara di kelas (Cubukcu, 2008). Penelitian lain juga 
menunjukkan tidak ada korelasi antara gejala kecemasan dan efikasi diri mahasiswa. Hal ini mungkin terjadi karena perbedaan kondisi populasi dan subjek dan instrumen yang digunakan. Instrumen yang digunakan dalam penelitian ini adalah General Health Questionnaire (GHQ-28) yang berisi pertanyaan pertanyaan terkait gejala kecemasan dan depresi (Faramarzi \& Khafri, 2017).

Mahasiswa tingkat akhir yang sedang mengerjakan skripsi di tengah pandemi wabah COVID-19 dihadapkan pada berbagai tantangan terkait proses penelitian, pengambilan data, perubahan metode dan kesulitan dalam hal konsultasi yang menyebabkan mahasiswa rentan mengalami kecemasan. Kecemasan apabila tidak diatasi dapat menimbulkan dampak negatif terhadap psikologis mahasiswa dan juga proses pengerjaan skripsi. Mahasiswa memerlukan strategi yang tepat untuk mengatasi kecemasan tersebut. Salah satu caranya adalah dengan meningkatkan efikasi diri.

Efikasi diri merupakan persepsi individu mengenai seberapa baik individu tersebut dapat menyelesaikan suatu tugas atau masalah yang dihadapi (Safitri \& Masykur, 2017). Efikasi diri merupakan keyakinan diri dalam melaksanakan tugas untuk mencapai hasil tertentu (Rustika, 2016). Saat dihadapkan masalah atau tugas, seseorang yang memiliki keyakinan untuk berhasil akan lebih optimis dalam melaksanakan tugas, mengambil keputusan dengan lebih tenang, berani menghadapi tekanan dan ancaman, serta dapat mengendalikan situasi. Sementara seseorang dengan efikasi diri rendah (tidak yakin dengan kemampuannya) akan mengalami kecemasan dan kesulitan dalam mengontrol situasi di sekitarnya (Shofiah \& Raudatussalamah, 2014).

Individu yang tidak menganggap diri mereka kompeten kehilangan motivasi untuk menyelesaikan tugas-tugas sulit dan fokus pada kemungkinan kegagalan yang dapat terjadi (AL-Baddareen et al., 2015). Seseorang dengan efikasi diri rendah memusatkan perhatian mereka pada berbagai kemungkinan kegagalan pada suatu tugas yang dapat mengancam diri (Listanto \& Demak, 2015). Seseorang dengan efikasi diri rendah juga tidak mencari peluang untuk memperoleh pengetahuan atau keterampilan yang diperlukan untuk menciptakan keberhasilan, termasuk membangun kepercayaan diri pada kemampuannya (Rustika, 2016). Salah satu alasannya adalah karena pandangan negatif pada kemampuan diri sendiri. Seseorang dengan efikasi diri rendah mungkin melihat pengalaman sulit sebagai ancaman dan mengaitkan hasilnya dengan pikiran negatif yang muncul dari diri sendiri. Ketidakmampuan yang dirasakan ini meningkatkan kecemasan dan biasanya menyebabkan efek negatif yang lebih besar pada kinerja (Shofiah \& Raudatussalamah, 2014).

Seseorang dengan efikasi diri yang tinggi mempunyai pandangan untuk sukses dan yakin akan kemampuan yang dimiliki (Shofiah \& Raudatussalamah, 2014). Pikiran positif akan membangun kepercayaan diri dan mempermudah pencapaian tujuan. Keyakinan ini juga memicu motivasi untuk berusaha dalam menyelesaikan berbagai tugas yang ada (Safitri \& Masykur, 2017).

Efikasi diri berperan penting dalam proses penyusunan skripsi. Bandura (1997) menjelaskan bahwa efikasi diri mempunyai 
hubungan dengan performa seseorang dalam menulis (Rustika, 2016). Seseorang dengan efikasi diri yang tinggi akan mempunyai semangat untuk melanjutkan tulisannya meskipun dihadapkan pada berbagai tantangan, serta mempunyai keinginan yang tinggi untuk mencapai tujuan/target yang telah ditetapkan (ALBaddareen et al., 2015).

\section{KESIMPULAN DAN SARAN}

Hasil penelitian menunjukkan bahwa terdapat hubungan antara efikasi diri dan kecemasan menyusun skripsi. Mahasiswa dengan efikasi diri yang tinggi mempunyai kecemasan yang rendah, begitu pula sebaliknya. Berdasarkan hasil penelitian, maka dapat disimpulkan bahwa efikasi diri dapat menururunkan atau meningkatkan kecemasan mahasiswa dalam menyusun skripsi. Sehingga, mahasiswa perlu meningkatkan efikasi dirinya agar dapat meminimalisir kecemasan yang muncul akibat pengerjaan skripsi.

Mahasiswa perlu membuat daftar tujuan yang ingin dicapai, sehingga terpacu untuk berusaha lebih mencapai tujuan tersebut. Mahasiswa juga harus mengidentifikasi hambatan dan pikiran negatif yang mungkin muncul dan membuat perencanaan terkait penyelesaian atau jalan keluar dari masalah yang mungkin muncul. Mengubah cara dalam melihat kegagalan dan menerima kegagalan sebagai sebuah proses belajar sangat membantu dalam mengubah cara berfikir terhadap diri kita. Selain itu mahasiswa dalam mengerjakan tugas akhir perlu melakukan berbagai macam hal untuk mengurangi kecemasan yang terjadi. Kegiatan yang dapat dilakukan diantaranya adalah tidur, bermain game, makan makanan yang disukai, menonton Niken Saraswati, dkk., Peningkatan Efikasi Diri Mahasiswa... film, atau melakukan kegiatan lainnya yang menyenangkan.

Institusi pendidikan harus bekerjasama untuk membantu mahasiswa dalam pembelajaran dan mengurus kepentingan akademik secara online, menyediakan layanan konsultasi online atau diskusi online dan pelayanan akademik secara online. Selain itu staff pengajar dan staff lainnya perlu membantu mahasiswa mengatasi masalah akademik timbul akibat adanya sistem WFH seperti masalah persuratan dan mekanisme layanan akademik selama pandemi COVID-19, sehingga hambatan dalam proses penyelesaian tugas akhir dapat diminimalkan.

Penelitian selanjutnya diharapkan dapat meneliti faktor-faktor lain yang mempengaruhi efikasi diri dan kecemasan.

\section{UCAPAN TERIMA KASIH}

Terimakasih peneliti sampaikan kepada dosen pembimbing yang telah membimbing dengan penuh kesabaran. Peneliti juga mengucapkan terimakasih kepada dosen penguji yang sudah memberikan evaluasi dan masukan yang membangun, serta kepada semua pihak yang membantu dari awal sampai akhir penelitian.

\section{DAFTAR PUSTAKA}

AL-Baddareen, G., Ghaith, S., \& Akour, M. (2015). Self-efficacy, achievement goals, and metacognition as predicators of academic motivation. Procedia-Social and Behavioral Sciences, 191, 2068-2073. doi: 10.1016/j.sbspro.2015.04.345

Annisa, D. F., \& Ifdil, I. (2016). Konsep kecemasan (anxiety) pada lanjut usia (Lansia). Konselor, 5(2), 93. doi: 
$10.24036 / 02016526480-0-00$

Cao, W., Fang, Z., Hou, G., Han, M., Xu, X., \& Dong, J. (2020). The psychological impact of the COVID19 epidemic on college students in China. Psychiatry Research Journal, January, 1-5.

Cubukcu, F. (2008). A study on the correlation between self efficacy and foreign language learning anxiety. Journal of theory and practice in Education, 4(1), 148-158. doi: 13049496

Faramarzi, M., \& Khafri, S. (2017). Role of alexithymia, anxiety, and depression in predicting self-efficacy in academic students. Scientific World Journal, 17. doi: $10.1155 / 2017 / 5798372$

Kristianto, P. H., Pm, S., \& Setyorini. (2014). Hubungan antara kepercayaan diri dengan kecemasan dalam menyusun proposal skripsi. Jurnal Satya Widya, 30(1), 43-48.

Listanto, V., \& Demak, I. P. K. (2015). kecemasan pada mahasiswa angkatan 2010 yang mengerjakan tugas akhir Program Studi Pendidikan Dokter FKIK UNTAD Tahun 2010. Jurnal Ilmiah Kedokteran, 2(1), 40-49.

Permana, H., Harahap, F., \& Astuti, B. (2016). Hubungan antara efikasi diri dengan kecemasan dalam menghadapi ujian pada siswa Kelas IX di MTS Al Hikmah Brebes. Jurnal Hisbah, 13(1), 51-68.

Rau, M. J., Rahman, A., \& Randalembah, G. R. (2017). Faktor risiko kejadian gangguan ansietas di Rumah Sakit Umum Daerah Ampana Kota Kabupaten Tojo Una-Una Tahun 2016. Jurnal Preventif, 8(1), 34-38.

Rismen, S. (2015). Analisis kesulitan mahasiswa dalam penyelesaian skripsi di Prodi Pendidikan Matematika STKIP PGRI. Lemma, I(2), 57-62.

Rustika, I. M. (2016). Efikasi diri: Tinjauan Teori Albert Bandura. Buletin Psikologi, 20(1-2), 18-25. doi: 10.22146/bpsi.11945

Safitri, D. P., \& Masykur, A. M. (2017). Kejuaraan nasional pada atlet tenis Lapangan Pelti Semarang. Jurnal Empati, 6(April), 98-105.

Shofiah, V., \& Raudatussalamah. (2014). Self-efficacy dan self-regulation sebagai unsur penting dalam pendidikan karakter (Aplikasi pembelajaran Mata Kuliah Akhlak Tawasuf). Jurnal Penelitian Sosial Keagamaan, 17(2), 214-229.

Siyoto, S., \& Sodik, M. A. (2015). Dasar metodologi penelitian (1st ed.). Yogyakarta: Literasi Media Publishing.

Widodo, S. A., Laelasari, L., Sari, R. M., Nur, I. R. D., \& Putrianti, F. G. (2017). Analisis faktor tingkat kecemasan, motivasi dan prestasi belajar mahasiswa. Taman Cendekia, 1(1), 67. doi: 10.30738/tc.v1i1.1581

Zhai, Y., \& Du, X. (2020). Addressing collegiate mental health amid COVID19 pandemic. Psychiatry Research, 288, 1-2. doi: 10.1016/j.psychres.2020.113003 